$10 \mathrm{IKC}-33$

\title{
FORMATION FEATURES OF THE EARLY-HERCYNIC ALKALINE-ULTRABASIC AND BASIC VOLVANIC COMPLEXES AND DIAMONDIFEROUS CRITERIA OF THE KIMBERLITES FROM ZIMNY BEREG AREA (NORTH-WEST OF ARCHANGELSK REGION, RUSSIA)
}

\author{
Tretyachenko VV, Bovkun AV, Garanin*KV, Garanin VK, Tretyachenko NG \\ JSC SEVRALMAZ/ALROSA, Archangelsk, Russia, M.V. Lomonosov Moscow State University, Moscow Russia
}

\section{INTRODUCTION}

Within the Kuloisky plateau and Onega peninsula in Zimnyi Bereg area (Archangelsk region, NW Russia), it is known already more than hundred intrusions of volcanites (pipes, stocks, sills and dikes), which are characterized by alkaline-ultrabasic and basic compositions (Fig. 1). Volcanites are located in different structures of the basement and a sedimentary cover. Intrusions can be described by significant variety of the diamond grade, mineral composition, internal structure, etc.

\section{ZIMNYI BEREG VOLCANIC COMPLEXES FORMATION FEATURES}

According the targets of the research efforts the main aspects of the formation analyzing, tectonic position, mineragenetic zoning and evaluation of the diamond potential and grade were done for all complexes of magmatic intrusions.

The achievement of research targets included following aspects of geological investigations: studying of sediment formations of the platform cover and the crystal basement by the description and detailed research of a core from structural-parametrical, prospecting, exploration and estimation drilling holes; using

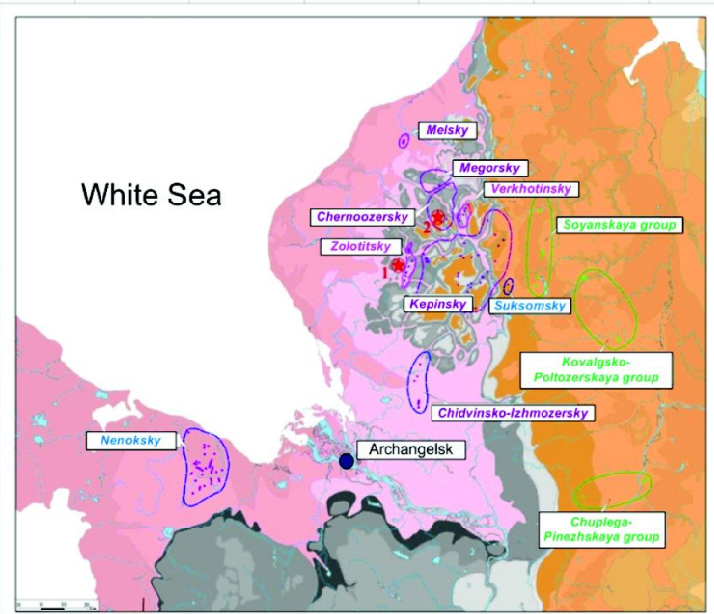

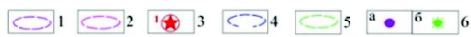

Fig. 1. Zimnyi Bereg area volcanites. Kimberlite and olivine melilitite complexes (1-5). 1-2 - Kimberlite-non-pyroxene alkaline picrites: Fe-Ti-type - Kepinsky, Megorsky, Chernoozersky, Melsky, Al-type - Zolotitsky, Verkhotinsky; 3 - Diamond deposits: 1 - M.V. Lomonosov, 2 - V. Grib; 4 - Subformation feldspar picrites-olivine melilitites: Al-type - Nenoksky, Chidvinsko-Izhmozersky, Suksomsky; 5 - Basalt complex groups of pipes Soyanskaya, Kovalgsko-Poltozerskaya, Chuplga-Pinezhskaya; 6 - Diatremes: a kimberlites, picrites, olivine-melilitites; $b$ - tholeiitic basaltse

gravimetric and seismic exploration data; complex studying of internal structure, petrography, geochemistry, mineralogy, diamond potential and grade of the Early-Hercynic volcanic formations. The drill-core description, thin sections study, paleontology and paleochronology 


\section{0 $^{\text {th }}$ International Kimberlite Conference, Bangalore - 2012}

reconstructions, chemistry analyzing and other methods of investigations were realized for different alkaline-ultrabasic intrusive complexes.

Early-Hercynic formation of Archangelsk region volcanites consist of: (1) alkaline-ultrabasic magmatites: kimberlites and related rocks of the Zimny Bereg and Onega Peninsuila and (2) Soyana-Pinezhsky complex of the dolerite-basalt pipes in the East part of Kuloisky plateau.

There were found two different subformations as parts of the alkaline-ultrabasic formation: (a) kimberlite-non-pyroxenite alkaline picrites Zimneberezhny megacomplex: Zolotitsky, Chernoozersky, Kepinsky, Megorsky, Verkhotinsky and Melsky complexes) and (b) feldspar picrites-olivine melilitites (NenokskoChidvinsky megacomplex: ChidvinskyIzhmozersky, Nenoksky and Suksomsky complexes).

Three periods were identified for EarlyHercynic (Late Devonian) circle of alkalineultrabasic and basic magmatic activity in Archangelsk region: (1) 410-390 m.y. (Kepinsky, Megorsky and Melsky complexes); (2) 387-375 m.y. (Chidvinsky-Izhmozersky, Suksomsky and Soyana-Pinezhsky complexes); and (3) 370-340 m.y. (Nenoksky, Zolotitsky (M.V. Lomonosov deposit), Chernorechinsky (V. Grib deposit) and Verkhotinsky complexes).

The tectonic position analyze of the crystalline basement was also done. There were indicated Kuloisky craton and Belomorsky mobile belt. Riphean formations are confined to contrast different structural-formation zones of the basement: (1) Pritimansky pericraton (Kolsky crustal block) and Kandalaksha-Dvinsky aulokogen (Belomorsky crustal block). Paleostructural and paleogeographic reconstructions for Early Cambrian and EarlyMiddle Carbon show the structure-controlling elements of the volcanic complexes, their formation, denudation and burial ages. The proved estimation of the diamondiferous potential and perspectives for discoveries of the new industrial

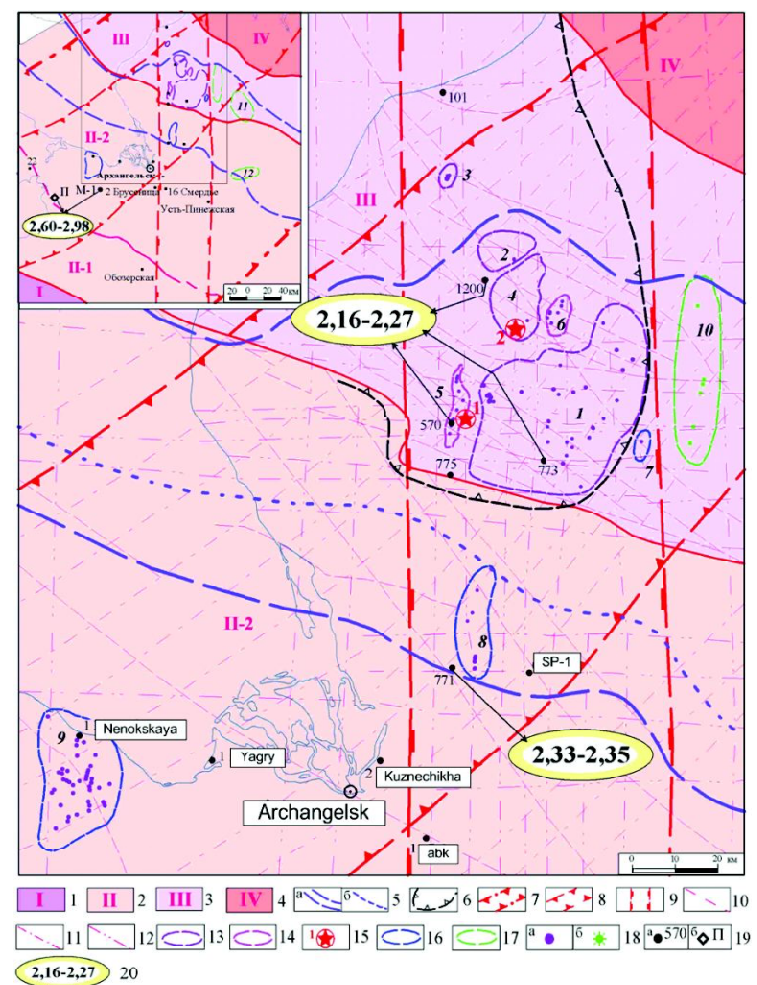

Fig. 2. Tectonic zonation of Zimnyi Bereg area: 1 - 4 Blocks of the $I^{\text {st }}$ rang: 1 - Karelian, 2 - Belomorian (II-1 - Nizhneonezhsky, II-2 Severodvinsky), 3 - Kola-Kuloisky 4 - Murmansky; 5 Paleoproterozoic tectonic-thermal reworked zone: à - zone borders, á - axe line Main Belomorian weld; 6 - Area of high electric resistance after $M T Z ; 7-9$-Zones of tectonic-magmatic activation: 7 - Baltic-Mezenskaya, 8 - Archangelskaya; 9 - Zimneberezhnaya; 10 - 12 - Tectonic faults: 10 - structure controlling - NW; 11-12 secant: 11 - NE, 12 - meridianal and width ; 13 - 15 - Kimberlite and melilitite-picrite complexes: $13-14-$ Subformation of kimberlites-non-pyroxene alkaline picrites: 13 - Fe-Ti type: 1Kepinsky; 2 - Megorsky, 3 - Melsky; 4 - Chernoozersky; 14 - Altype: 5 - Zolotitsky, 6 - Verkhotinsky; 15 -Diamond deposits: 1 M.V. Lomonosov, 2 - V. Grib; 16 - Subformation of feldspar picritesolivine melilitites (Al-type): 7 - Suksomsky, 8 - ChidvinskoIzhmozersky, 9 - Nenoksky; 17 - Basalt complex groups of pipes: 10 - Soyanskaya, 11 - Kovalgsko-Poltozerskaya, 13 - ChuplegaPinezhskaya; 18 - Diatremes: à - kimberlites, picrites, olivine melilitites, $\mathrm{b}$ - tholeiitic basalts; 19 - deep drilling holes, foundament penetrated, their numbers, names (à), Pokrovsky open-pit (b); 20 Sm-Nd values of absolute age (Samsonov et al., 2008)

diamond deposits is given for different range of the mineragenetic territories (Fig. 2).

The Earth crustal block with kimberlites and convergent rocks from Zimny Bereg and Onezhky peninsuila was identified in kimberlite area range 


\section{0 $^{\text {th }}$ International Kimberlite Conference, Bangalore - 2012}

of the southeastern White Sea territory, which at the same time is a part of the Baltic-White Sea alkaline-ultrabasic subprovince.

Allocation of the second (zone) and third (field) ranges of the mineragenetic units is based on the identification of the formation taxons: subprovince (megacomplex) - kimberlite (picrite) zone - kimberlite (picrite) field. Therefore, the main mineragenetic taxons in southeastern White Sea area are: (1) Zimneberezhny kimberlite zone, include M.V. Lomonosov and V. Grib diamond deposits and low- or non-diamondiferous

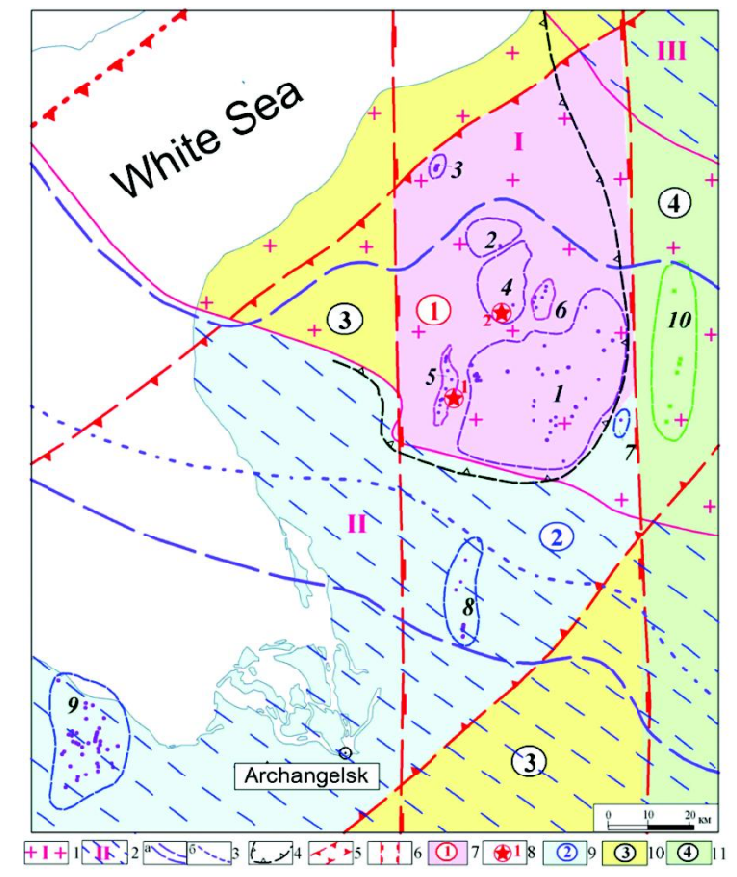

Fig. 3 Zimnyi Bereg area basement structure and mineragenetic units. 1 - Kola-Kuloi block; 2 - Belomorian (II) and - Murmansky (III) blocks; 3 - Paleoproterozoic tectonic-thermal reworked zone: à zone borders, $\mathrm{b}$ - axe line Main Belomorian weld; 4 - Areas of high electric resistance after MTZ; 5, 6 - Formation-mineragenic zones: 5 - Archangelskaya; 6 - Zimneberezhnaya; 7, 8 - Kimberlites area (area of ultrabasic alkaline volcanism) of southern-east White Sea: 7 - Zimneberezhny district of diamondiferous kimberlites-nonpyroxene picrites (Zolotitskoe (5), Chernoozerskoe (4), Kepinskoe (1), Verkhotinskoe (6), Megorskoe (2) and Melskoe (3) fields); 8 Diamond deposits: 1 - M.V. Lomonosov, 2 - V. Grib; 9 Archangelsk district of feldspar picrites-olivine melilitites (Nenokskoe (9), Chidvinsko-Izhmozerskoe (8) and Suksomskoe (7) fields); 10 - Districts with unclear diamondiferous potential; 11 Soyana-Pinezhsky district of basalt pipes
Verkhotinskoe, Kepinskoe, Megorskoe and Melskoe fields, and (2) Archangelsk zone of the feldspar picrites-olivine melilitites, include Nenokskoe, Chidvinskoe-Izhmozerskoe and Suksomskoe fields (fig. 3).

Mineragenetic zoning on diamonds was done on the basis of alkaline-ultrabasic formations analyze and their tectonic positioning. Different range of the diamondiferous territories was identified for kimberlites in "region-area-field" scale.

\section{STUDY RESULTS}

Generally geological structure and substantial composition of kimberlites and convergent rocks from Zimny Bereg are similar to analogous rocks from Yakutian, African and others kimberlitic provinces, but there are some distinctions were identified: 1. A discrete of substantial composition's typomorhic features, geological structure, age, diamond grade for different rank of volcanic taxones and individual pipes; 2. Wide development of two distinct mineralogical and petrochemical rock types $-\mathrm{Mg}$ $\mathrm{Al}$ and Fe-Ti found; 3. Drastically low content of heavy fraction and HP-HT minerals; 4. Considerable degree of lateral and vertical heterogeneity of the rocks in pipes, especially in multiphase diatremes; 5 . Clearly pronounced explosive phases, which in some cases led to contamination by xenogenic material and intense saponite secondary mineralization; 6 . Two subformations - a) kimberlites-non-pyroxene bearing picrites and b) feldspar picrites-olivine melilitites are quite clearly marked by indicator petrological signs; 7. Industrial diamondiferous kimberlites from Zolotitskoe and Chernoozerskoe complexes formed during the very Late Famennian-Early Visei era, which is very close to the analog age era for industrial diamondiferous pipes from Malo-Botuobinskoe, Alakitskoe, Daldynskoe and Verkhne-Munskoe kimberlitic fields of Western Yakutia; 8. According to 
mineralogical and petrochemical characteristics industrial diamondiferous Mg-Al-kimberlies of Zolotitsky complex (low Ti-kimberlites) can be compared to the kimberlites from the Nakynskoe field (Yakutian province), and industrial diamondiferous Fe-Ti-kimberlites of Chernoozersky complex (moderately Tikimberlites) to kimberlites from the MaloBotuobinskoe, Daldynskoe, Alakitskoe fields (Yakutian Province); 9. By major isotope characteristics industrial diamondiferous kimberlites of the Zimnyi Bereg almost similar diamond-bearing kimberlites from Nyurbinskaya pipe (Yakutian Province) and Kaavi-Kuopio pipes (Eastern Finland). At this case, in relation to kimberlites groups I and II in South Africa, they occupy an intermediate position and can be separated into independent Archangelsky type; 10. Typomorphic indicative features of $\mathrm{Fe}-\mathrm{Ti}$ kimberlites and non-pyroxene alkaline picrites Kepinsky and Megorsky complexes can generally confident enough to compare them with the Group I kimberlites of South Africa and high Tikimberlites and alkaline picrites from northern fields of Yakutian diamondiferous province; 11. Feldspar picrites and olivine-melilitites from Nenoksko-Chidvinsky megacomplex show similarity with Al-kimberlites of Zolotitsky complex and phlogopite picrites Verhotinsky complex, but by our opinion that are closer alnoite-picrites, including associated carbonatites; 12. Petrological features of Soyana-Pinega dolerite-basalt complex correspond tholeiitic basalts of the normal series from continental intraplate environment that allows considering this complex as part of Early Hercynic dolerite-basalt formation of the East-European platform.

\section{CONCLUSION}

The study results of age formation, geological structure, petrography, mineralogy, petrochemistry, geochemistry and diamond grade of the Early Hercynic kimberlitic complexes, convergent rocks and basaltic pipes from Zimny Bereg area (North-East of Archangelsk region, Russia) was presented. On the basis of these materials the typing of rocks was done with an allocation of the basic rank taxons: regional formation-subformation (megacomplex)volcanic complex.

The results of the study provide the elaboration of the more efficient strategy for prospecting and exploration works on diamonds in NW Russia. 